\title{
A Methodological Approach for Evaluating Brownfield Redevelopment Projects
}

\author{
Francesco Cappai ${ }^{1, * \mathbb{D}}$, Daniel Forgues ${ }^{1}$ and Mathias Glaus ${ }^{2}$ \\ 1 GRIDD-ÉTS École De Technologie Supérieure, 1100 Notre Dame W, Montréal, QC H3C 1K3, Canada; \\ daniel.forgues@etsmtl.ca \\ 2 STEPPE-ÉTS École De Technologie Supérieure, 1100 Notre Dame W, Montréal, QC H3C 1K3, Canada; \\ mathias.glaus@etsmtl.ca \\ * Correspondence: francesco.cappai.1@ens.etsmtl.ca; Tel.: +1-514-396-8800
}

Received: 26 March 2019; Accepted: 18 April 2019; Published: 21 April 2019

\begin{abstract}
In recent decades, municipalities around the world have been developing community policies and seeking to apply them in their cities. They use methods for exchanging information and opinions on decisions, policies, plans and strategies and involve and consult with the community and stakeholders in all aspects of the decision-making process. The application of methods for thoughtful planning has become the goal of policy makers to improve the lives of citizens and stop the expansion of the city into the countryside. The aim of this article is to integrate the notion of sustainability into a methodological approach, taking into account the actors involved in the decision-making phases, the objectives, and the local indicators in an urban redevelopment project (brownfield). Our approach is based on an analysis of 21 articles and on a transversal and cross-cutting view of the interdisciplinary themes of sustainable development by inserting the main actors into decision-making in urban projects and by selecting local indicators. We put in place a methodological approach for the evaluation of urban projects that takes into account local expectations. The goal is to identify and classify the elements that are needed for decision making, including the indicators related to environmental and socio-economic components, in order to develop an effective evaluation tool. This research contributes to the knowledge of project evaluation tools in the specific context of a city.
\end{abstract}

Keywords: sustainable building; brownfield; sustainability assessment; subjectivity; adaptability; urban development; decision making planning

\section{Introduction}

In recent decades, the evolution of urban planning has been oriented towards the principles of sustainable development. The urban population has grown rapidly over the past century (US Census Bureau, (World Population), 2015) [1]. In addition, demand for land has increased rapidly to meet the needs of the population settling near urban centers [2]. The loss of open space and farmland, climate change, loss of biodiversity and environmental pollution are major issues that must be taken into account in urban planning. The rapid increase in the demand for land has dramatically increased the total value of real estate over the last 40 years (Isaac, 2002 cited by Chen, Hipel et al. 2009) [2]. All of these factors force municipalities to take a lead in the planning of cities and their components [3]. It is the stakeholders involved in urban policies that have been called upon (and should be called upon, if they have not already) to make strategic decisions in the development of their cities and territory [4].

It is through projects at the local level—sustainable neighborhood development-that the growing number and diversity of these operations reflect the lack of studies on the approaches and development processes specific to this neighborhood scale, as well as on the question of adapting such an approach in each urban context [5]. The redevelopment of brownfield sites within urban areas is now considered 
a sustainable land use [6,7]. The use of a methodological approach to brownfield redevelopment should be based on an assessment of the existing context, the external context of the site and the use of local indicators [5]. This will enable decision-makers to better identify local expectations in terms of improving social and economic conditions in order to attach citizens to their neighborhood and engage them and improve the development of the neighborhood [8,9].

Brownfields have gained the attention of town planners, municipalities and academics because they are spaces that can be used to accomplish multiple sustainability goals. Indeed, economic issues are often highlighted when evaluating the potential conversion of these wastelands. The integration of brownfields into urban planning is a process in which more and more actors are becoming involved, each with their own specific objectives. The actor's interest leads them to consider various rehabilitation strategies and thus, a multitude of possible uses for brownfields. The majority of rehabilitation strategies are often linked to the revival of industrial activity, in which projects are adapted to new high-tech industries and new economic endeavors. Meanwhile, several conversions have been made for the benefit of residential projects and recreational tourism. The replacement of the industrial function often leads to the creation of public or semi-public green spaces aimed at strengthening the social mix of the neighborhoods affected. Brownfields have a great social impact when they are part of a system of open spaces that act to structure the urban form [10]. Brownfields can reunite neighborhoods previously cut in half, re-creating links, or, on the contrary, constitute buffer zones between differentiated social or functional spaces. It is from this perspective that the redevelopment of brownfields must consider the growth of urban centers, their density and mixed use, whose overall quality meets a comprehensive vision of sustainability [11]. However, a number of parameters are needed to apply the concept of sustainable development if we are to respect the principles of sustainable neighborhoods and take into account the mitigation of the impact of development on the less fortunate [5]. Meanwhile, municipal administrations generally focus on the development of its spaces and the potential increase of their tax revenues, whereas ecologists wish to foster more ecological balance and naturalize sites, often to promote the restoration of water courses and thereby reduce the burden on sewer systems. Promoters are interested in devoting land and possibly recycling buildings for market-rate residences, as that could be highly high profitable. The needs and the expectations of the local community are almost never taken into consideration. It is important to mention that brownfields can be seen as a unique opportunity for municipalities, as these spaces can help to give a local community an identity, and via the consultation process, offer area residents a meaningful voice in sustainability assessment.

We have chosen to develop a methodological approach addressing the complexity of particular local contexts (industrial wastelands), because we believe that it is this neighborhood scale that we can identify and apply solutions to most of the problems, which we can then expand to a larger scale. These include the contextualization of the site to the rest of the territory, the appropriate filling of vacant spaces, providing desired services to citizens and the issues involved with historical heritage. This approach also encompasses promoting the use of less polluting materials, without forgetting the social mix by including affordable and social housing, as well as schools, parks, commercial spaces, and community centers.

The main objective of our research is to develop a methodological approach for analysis and decision-making. The goal is to identify and classify the elements that are needed for decision making, including the indicators related to environmental and socio-economic components, in order to develop an effective evaluation tool. This article presents the first part of the research to identify the literature for the intervention framework. The three steps of the proposed approach are as follows: (i) Identification of the stakeholders involved in a brownfield redevelopment process and their involvement in the project phases; (ii) identification of the dimensions covered in each study and the association of thematic areas; and (iii) identification and classification of indicators for each dimension. At the end of our analysis, we will propose a list of indicators that can be used in the decision-making phase and in evaluating the success of the project. This classification is the basis for proposing an effective methodological approach for brownfield redevelopment. 


\section{Awareness of Brownfield Rehabilitation}

Recently, the sustainability parameters used by designers and many municipalities have ranged from environmental design to measures of economic and social success, all promising a high quality of life in new urban contexts [5]. The multi-faceted benefits of redeveloping brownfield sites have been studied in a number of works, ranging from the specific technical benefits to economic and social advantages.

The World Summit on Sustainable Development (2002) and the Paris Conference on Climate Change (2015) laid the foundation for sustainable improvements in economic development, social development and environmental protection, including work towards reducing the consumption of fossil fuels to mitigate the production of greenhouse gases.

The concept of sustainable development is related to the "carrying capacity" of a territory, now a commonly used sustainability parameter. This parameter, which Wackernagel and Rees (1998) [12] have named the "Ecological Footprint", is the area of land and or water that is needed to meet the resource needs and process the waste generation of a population. This concept also includes the protection of natural resources and habitats, and so the redevelopment of industrial sites can be perceived as meeting these objectives. The redevelopment of brownfield sites is considered sustainable land use [6]. As defined by the US EPA $(1992,2012)$ [2], brownfields are abandoned industrial sites that are contaminated, vacant, underutilized and harmful to the surrounding environment. Brownfields, as defined by US EPA (2012) [2] and other organizations of several governments, are spaces integrated in the urban fabric, often near the city center of the major agglomerations of industrialized countries. Sometimes brownfields are found in areas outside a city, but adjacent to virgin or arable land, in small communities, and in rural communities. For brownfields within the urban fabric, while they are indeed spaces where there is no true community identity, they very well could be spaces where citizens find part of their identity through history and its urban components in these spaces. Brownfields are often considered a burden for municipalities that cannot "make them profitable" or otherwise access their potential for reuse.

Until just a few decades ago, brownfields were seen as barriers to a city's development because of the high cost of decontamination, a major obstacle for landowners and municipalities who had decided to leave these lands abandoned rather than invest in cleaning them up [13]. In addition, the lack of interest in the redevelopment of industrial wasteland was caused by cultural stagnation and underdevelopment of its economy that had kept the population dubious and therefore unable to arouse the interest of investors [14,15]. In another perspective, the absence of rehabilitation projects can be explained by insufficient social or economic demand [16]. In addition to the high cost of decontamination, repurposing old buildings can be very costly and requires a major effort to integrate them into the neighboring context. As stated by Sardinha et al. (2013), reconverting a brownfield site must promote the quality of housing as well as the creation of affordable and social housing in order to encourage the investors to take an interest in the rehabilitation of brownfield by the profitability of the project. Nevertheless, contaminated sites have strengths such as space, potential quality of life, and proximity to the city $[9,17]$.

The sheer volume of brownfields around the world is staggering. Just a few examples can help to understand their impact on local economies. There are about 1,000,000 brownfield sites in the United States, and in Canada there are over 23,078 federal sites that are contaminated or likely to be contaminated [11,12]. The Inventory of Federal Contaminated Sites (IFCS) lists 15,386 sites as closed (Government of Canada, Treasury Board of Canada Secretariat) [18]. Depending on their location, one can imagine the magnitude of the environmental, social and economic benefits that could be realized with their redevelopment. Efforts to reclaim brownfield sites often come from local will and require government actions. The decisions of local actors often favor economic or environment issues rather than social issues. Conflicts arise when the actors involved have different and sometimes very divergent interests. For example, the interests of community groups may not be in line with to the reconversion of local economies, an industrial revival or with a reorientation towards tourism and 
recreation. As an example of the divergent groups involved, studies conducted by De Sousa [13,19] in Canadian cities have highlighted the importance of private investment because of the high cost of rehabilitating these sites, to the detriment of community interests. Other studies by Adams and Watkins (2002) [20] and Cappai et al. (2018) [5] focus on the need for a methodology to achieve sustainability goals. These studies have shown that, without an adequate methodology, there is a high risk that a project will not meet its original objectives.

A number of studies have considered the need for an effective evaluation tool to improve the lives of the local citizens and to achieve environmental and economic goals. Indeed, there are now several evaluation tools for project lifecycle assessment as well as for decision-making. For example, the US Green Building Council's (USGBC) Leadership in Energy and Environmental Design (LEED) [21] guidelines have played an important role in addressing the environmental impacts of the construction industry. As of 2015, in U.S. and Canada, more than 40,000,000 government and institutional buildings in the US were LEED certified (USGBC, 2016). Other directives and programs have been developed and utilized in other countries, for example BREGlobal's BREEAM program in U.K. [22], the CASBEE [23] tool in Japan, and the International Initiative for a Sustainable Built Environment (SBTool) [24].

All of these tools, although they have been used by many different organizations and include programs for evaluation at different scales of intervention (including programs for the evaluation of brownfields), are particularly lacking in the use of indicators, as they do not cover all dimensions of sustainability [25-27]. Methods of evaluating the results of brownfield projects are still required, as most of the sustainable evaluation tools are not capable of measuring the effectiveness of urban regeneration projects, and especially of taking into account both the objectives of sustainability and the expectations of the local community [28]. In a study conducted by Pan et al. (2016) [29] in the city of Chicago (USA) whose focus was urban development policies and their impacts on ecosystem services at different scales devised a dynamic model of land use. The model developed was used to analyze the shift from a traditional ecosystem services valuation approach to an approach integrating spatio-temporal dynamics encompassing a range of potential drivers of change that take into account the complexity of the site. The results have been that land-use change impose land restrictions on the growth of the economic sector through a competitive placement and also affect the spatial externality of production. [29]. For example, Hemphill, McGreal and Berry (2004) cited by Wedding (2007) [30] used a method to measure the effectiveness of urban redevelopment projects with sustainability objectives in mind, but that method used parameters that were not focused on brownfields. Bacot and Dell (2006) [31] suggested indicators to measure the viability of government brownfields programs taking into account the environmental and economic dimensions, but neglected to include indicators to assess the livability (e.g., affordable and social housing, and family services) or the ecological performance of new structures. In addition, their system does not assess the success or failure of rehabilitation.

Nyerges (2016) [17] in describing the problems of sustainable urban development, the decision process and the information tools related to the studied area, based his work with a geo-space tool to take into account the points of view of stakeholders to align with the interests at stake to make complex decisions. Indeed, his tool noted that the simultaneous consideration of social, economic, and environmental conditions can help to characterize housing, transport, surface water, and other systems when taking into account the complexity of durability. However, it is important that before making a decision it is necessary to know the impacts of the proposed designs and the target objectives of the management of sustainability, according to the issues of the projects to be pursued [17].

Other studies have highlighted the problem of involving stakeholders in the decision-making phase. Indeed, decision making is important for the success of a project. For example, in studies on the success of brownfield redevelopment, De Sousa (2006) [13] emphasized decision-making, as he found that the collaboration between stakeholders is often insufficient and sometimes absent. In a study evaluating the redevelopment of a brownfield site in Montreal, Cappai et al. (2018) [5] noted that the stakeholders only evaluated the project in the design phase. Indeed, that study demonstrated the need to evaluate a project during all of its phases (from design to completion and use). The issue 
of stakeholder participation is at the heart of researchers because local governments measure their projects in economic or environmental terms, but not in social and cultural terms [30].

\subsection{Stakeholder Input into Decision-Making}

In the process of project evaluation and decision-making, stakeholder input is fundamental to implementing territorial development policies that follow the principles of sustainability and meet local expectations. In the case of brownfields, the groups of actors that play a central role are usually the landowners, investors (who provide the capital) and developers (who carry out the project). These actors are directly concerned in the development of brownfields because of their financial interests [15,32]. According to De Sousa (2006) [13], the use of brownfield land for environmental purposes is seldom taken into consideration by investors and landowners, as their main purpose is to maximize the capitalization of these lands; converting them, for example, into a residential development. In most cases, developers are the most influential actors in the development of urban projects because they are focused on the real estate market [28].

The groups of traditional public actors, (elected officials, urban planners, community activists) who have the most competence in the management of local areas, seek to optimize the use of urban spaces to enhance city neighborhoods (preserving built and landscaped heritage), promote economic and social development, limit or even reverse the increasing needs for energy, ensure the health and safety of populations, and finally create a local dynamic around rehabilitation projects [6,33,34]. As plans move forward according to these priorities and thepossibly conflicting priorities of developers, academicians and traditional public actors can play the role of attracting and influencing investors (groups of private actors) to create favorable conditions for economic and urban development [35-37]. Normally, public actors are not included in the process of project development, as they are rarely consulted at the beginning of project planning. Government public actors (at the level of federal, state and local administrations), often engage technicians or sociologists for the subsequent phases, as these professionals may offer improved management of the process and can increase a project's chances of success. Indeed, government public actors generally do not have a solid grasp of the project cycle and so they prefer to engage with consultants, academics, or associations and institutions.

Academic experts occupy an intermedial space, on the one hand part of the project management, on the other hand, open to the greater population, forming an interface between these two groups of actors. They play the roles of translator, smuggler, media messenger and viewscreen [38]. According to Sardinha (2013) [39], "public promoters", in addition to official and professional experts, can also solicit and even mobilize "lay experts" (citizens with special experience), building on their practical knowledge acquired from their active participation in the daily life of their neighborhood in proximity to the brownfield. Local actors, including the residents, neighbors, users and other citizens that constitute the "local community", want to improve the quality of life and the state of their urban environment [5]. This local community can express and consolidate local expectations through various actions and initiatives to promote conversion strategies and local development. Involving local citizens in the planning of conversion projects is an important factor for the viability of a project, as they can bring their unique experience of the territory, including observations and knowledge to the other stakeholders, thereby creating the conditions for a project that will be good match for the needs of the local population [28,39].

Stakeholders can contribute to strengthening the project development process and to the implementation of effective urban policies to improve the quality of life of local citizens while improving the economic and environmental conditions of the territory. Stakeholder groups should be able to position themselves to influence urban projects. Local brownfield developments will more likely be successful if they reflect the results of local decision-making consultations that integrate the objectives of all of the relevant stakeholders. 


\section{Proposed Methodological Approach}

The analysis is based a selection of 21 articles related to restructuring case studies of North American and European brownfields. A multidisciplinary approach is used to consider the players involved in all phases of the project.

The first part of the research consists of a report on methodological approaches and frameworks; international tools that are completed or under development. The identification of these fundamental elements will identify their roles and their organization in the redevelopment project structure. Our analysis is based on the identification of criteria, targets. and indicators. The objectives are to propose a set of criteria that characterize urban redevelopment projects and to identify the dimensions and stakeholders that will best select and classify the indicators associated with each dimension.

As shown in Figure 1, the proposed methodological approach consists of three main steps. All the stakeholders involved in the redevelopment process are identified in the first step.

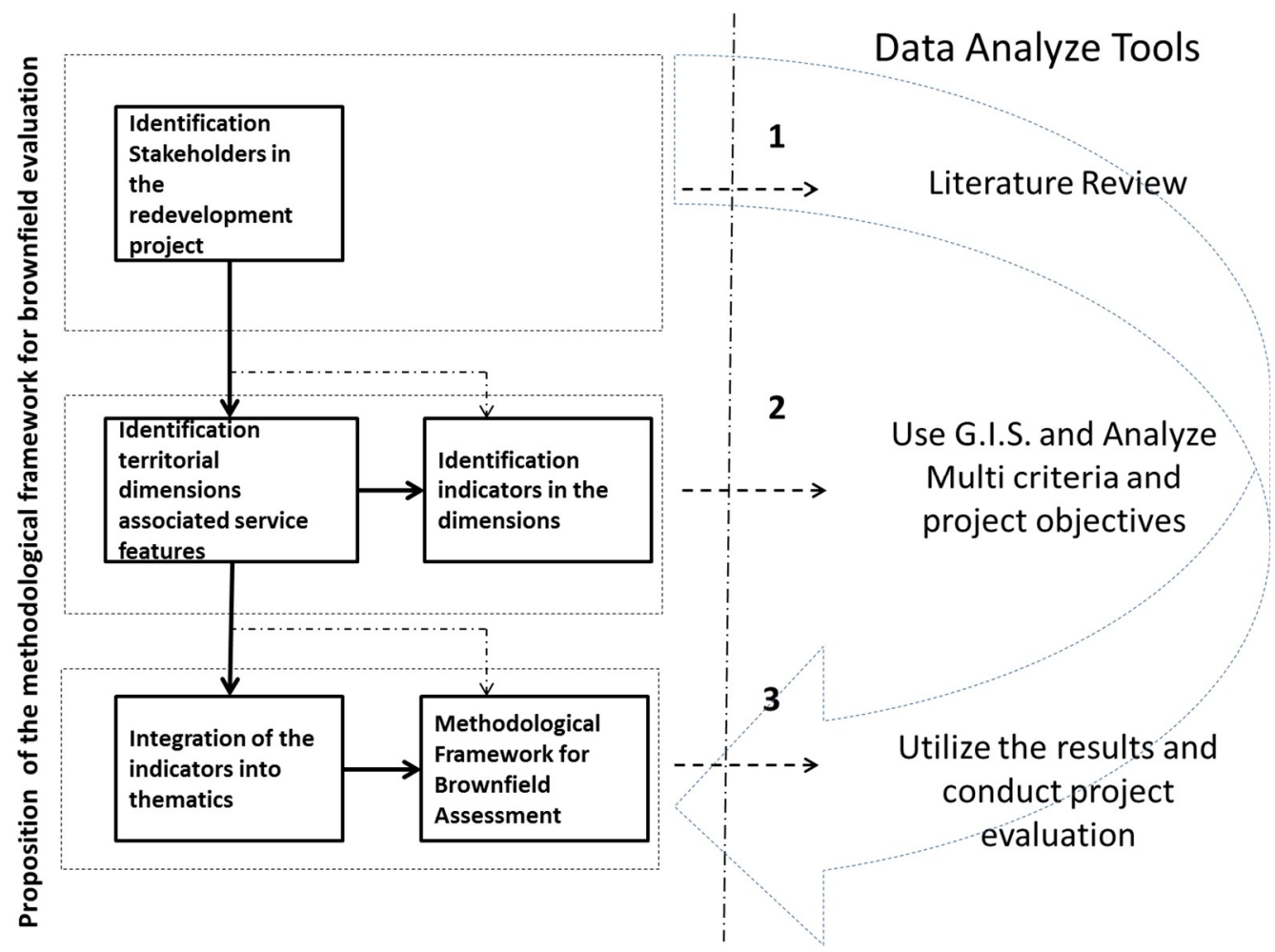

Figure 1. Methodological approach for the evaluation project.

An inclusive vision of stakeholders will be incorporated, considering a player as any stakeholder group or individual that is directly or indirectly influenced by the redevelopment process (Freeman (1984); Mitchel et al. (1997) cited by Sardinha et al. 2013 [39]).

After identifying the stakeholder groups involved in decision-making, these stakeholders are grouped according to the different categories and placed in each stage of the rehabilitation project. We recognize that the interrelationship of stakeholders between project phases must be specific at each stage that connects common stakeholder groups.

In the second step, we identify the territorial information associated with the services and at the same time identify the indicators related to the environmental and the socio-economic dimensions.

The indicators for each area are classified, taking into account their interrelations. For example, measures to reduce resource consumption lead to reduced project costs, which are also the result of promoting sustainable lifestyles in terms of consumption. This grouping makes it possible to take into account the links and interdependencies between dimensions and their associated indicators. In this step we use the G.I.S. for the identification of the indicators and a multi-criteria analysis is 
for the prioritization of the indicators in each dimension that are useful in the evaluation of the project. The use of G.I.S. is focused on territory analysis specifically on brownfields and surrounding areas. It is important to use this tool to identify the territorial dimensions associated with the services functionalities. Similarly, using maps available to municipalities and also through the use of georeferenced aerial photos. GIS is composed of different layers of geographic reference information. It is a technology that allows you to visualize and analyze data from a geographical perspective, allowing us to view the desired information on a map. In addition, a hierarchical multicriteria analysis (AHP) is applied to synthesize geographic information to select data that responds to priorities and preferences of citizens. This information includes criteria based on territorial characteristics and the location of the functions essential to the quality of life of citizens. This approach is a way to represent the true diversity and distribution of services in a territory.

In the third step, we first integrate the indicators in the thematic fields of sustainable development into the project process by constructing an analysis grid for the characterization of sustainable neighborhoods and then construct a synthetic presentation of the logic of developing sustainable neighborhood projects, based on a cross-tabulation to the application and assessment of the methodological framework. The working method is based on a review of the literature on the approaches in use and the existing evaluation tools. At the beginning of our process, we identify, select, and classify the elements needed for the cross-sectional understanding and characterization of brownfields.

We have been careful to draw the essential phases of a project in general and not to limit ourselves to a specific type of project (renewal, new development, etc.). The actors involved in sustainable neighborhood projects are identified and classified according to several criteria that we will explain later. We base our studies on the subject, on the different proposals of categorization and on organization. The project actors are organized into groups in our classification proposal in order to establish our analysis grid and to identify the environmental and socio-economic indicators in each thematic field. Our work consists of identifying and classifying the thematic fields that encompass all three dimensions of sustainable development. We rely on specific neighborhood level assessment and/or implementation tools and methods, as discussed in the previous section, to develop an inventory of the thematic areas addressed. Finally, we determine the most-representative thematic fields and environmental and socio-economic indicators.

\subsection{Stakeholder Identification (first step)}

Following the literature review (21 relevant articles on brownfield redevelopment) height stakeholder groups were identified. The analysis in these articles led us to reflect on the need for a renewal of the identification of the stakeholders involved in a brownfield redevelopment project. Their involvement was classified based on the respective project phases (Table 1). The goal was to identify the level at which each group of stakeholders is involved in decision making. It is in this context that the roles of these stakeholders become more complex and varied. Without going exhaustively into the modality of participation, we can distinguish the groups of key stakeholders in a sustainable project process. As shown in Table 1, these actors have been classified into eight groups according to their level of intervention and also in terms of their participation in the project hierarchy according to their discipline. The participation of stakeholder groups in the project phases is essential, but each stakeholder group must contribute specifically at certain phases of a project to achieve a successful sustainable urban redevelopment project. We identified two levels of participation: Essential and conditional. The first five stakeholder groups are classified as essential, while the last three groups are considered to have conditional participation in the design phase and project assessment. This latter classification is given to citizens who had not yet been included in the project phases [40-43].

This approach puts people at the centre of decision making and permits them to play a decisive role in the evolution of new solutions and to promote sustainability $[41,43]$. This group of players can 
be a driving force that not only motivates new policy decisions and the actions of professionals, but who also intervene directly in a project $[41,44,45]$.

Table 1. Public and Private Stakeholders Groups.

\begin{tabular}{cc}
\hline Stakeholders Groups & Public or Private \\
\hline National Policy Makers & National Policy, Ministerial, Administration \\
\hline Local Policy Makers & City and Community \\
\hline Institutions and Associations & $\begin{array}{c}\text { Urban services, Service companies, Associations, Local } \\
\text { housing authorities, Non-governmental partners, } \\
\text { Academics, Building managers }\end{array}$ \\
\hline Project Sponsors & Investors, Developers, Private landlords \\
\hline Experts & Urban planners, Engineers, Experts, Renovation \\
agencies
\end{tabular}

\subsection{Identification of Dimensions and Thematic Fields and Identification of Indicators in their Dimensions (second step)}

In Table 2 are listed the 21 items that we considered. Of the 21 selected articles, 13 are based on the three classical dimensions of sustainable development, environmental, social, and economic. Only eight articles stress the importance of adding and evaluating appropriate indicators of socio-cultural dimensions. Addressing only one or two themes is not enough to implement a process for achieving sustainable urban development. As several authors have indicated $[39,42,44,47]$, the objectives of sustainability must be addressed in order to achieve an approach that deals with registering a redevelopment project in the urban fabric in a sustainable way [28]. We chose a combination of thematic fields, aggregated through an analysis of case studies (see Table 3), because we consider it essential to contextualize the urban redevelopment project to the rest of the territory. The results of our analysis highlighted that only a few authors used thematic fields for each dimension; we have diversified their indicators by placing them in the appropriate thematic fields. Table 4 shows the indicators of each author, classified in their dimensions and thematic fields.

Table 2. Indicators Found in the 21 Articles Selected.

\begin{tabular}{cr}
\hline Authors & and Article Context \\
\hline$[46]$ & A Case Study of an Ethnically Mixed Neighbourhood \\
\hline$[7]$ & Site Prioritization and Selection Process for Brownfield Redevelopment \\
\hline$[19]$ & Measuring -level success in brownfield redevelopments \\
\hline$[30]$ & Chen, Y., et al.,(2009) - A strategic classification support system for brownfield \\
redevelopment
\end{tabular}


Table 2. Cont.

\begin{tabular}{|c|c|}
\hline Authors & and Article Context \\
\hline [48] & $\begin{array}{c}\text { Allocating risk capital for a brownfields redevelopment project under hydrogeological and } \\
\text { financial uncertainty }\end{array}$ \\
\hline [49] & $\begin{array}{c}\text { Reversing urban sprawl: A reclaimability index approach for reviving downtown } \\
\text { Brownfields }\end{array}$ \\
\hline [33] & $\begin{array}{l}\text { Evaluation of the environmental impact of Brownfield remediation options: comparison of } \\
\text { two life cycle assessment-based evaluation tools }\end{array}$ \\
\hline [39] & $\begin{array}{l}\text { A sustainability framework for redevelopment of rural brownfields: stakeholder } \\
\text { participation at SÃO DOMINGOS mine, Portugal }\end{array}$ \\
\hline [4] & $\begin{array}{l}\text { No perfect tools: Trade-offs of sustainability principles and user requirements in designing } \\
\text { support tools for land-use decisions between greenfields and brownfields }\end{array}$ \\
\hline [34] & $\begin{array}{c}\text { Countering decline of industrial sites: Do local economic development policies target the } \\
\text { neediest places }\end{array}$ \\
\hline [50] & $\begin{array}{l}\text { An integrative methodology to improve brownfield redevelopment planning in Chinese } \\
\text { cities: A case study of Futian, Shenzhen }\end{array}$ \\
\hline [8] & The regenerative approach to model an integrated urban-building evaluation method \\
\hline [26] & Urban Regeneration in Historic Downtown Areas: An Ex-Ante Evaluation in Athens \\
\hline [51] & A Sustainable Urban Regeneration Strategy for Hong Kong \\
\hline [52] & $\begin{array}{l}\text { Success factors for sustainable urban brownfield development: A comparative case study } \\
\text { approach to polluted sites }\end{array}$ \\
\hline
\end{tabular}

Table 3. Dimensions and individual thematic fields in the 21 articles.

\begin{tabular}{|c|c|}
\hline Dimension & Thematic Fields \\
\hline \multirow{3}{*}{ Environmental valuation } & $\begin{array}{l}\text { 1) Natural Resource Management (Storm water, sewage, alternative energy, etc.), } \\
\text { biodiversity, quality of natural areas }\end{array}$ \\
\hline & $\begin{array}{l}\text { 2) Environmental protection (floodplains, rivers, lakes, parks, wetlands, animals, } \\
\text { etc.) }\end{array}$ \\
\hline & 3) Improved comfort and health (site pollution ) \\
\hline \multirow{2}{*}{$\begin{array}{l}\text { Equitable social value } \\
\text { and social responsibility }\end{array}$} & 4) Strengthening cohesion and social equity \\
\hline & $\begin{array}{l}\text { 5) Enhancement of the architectural (buildings and materials) and historical } \\
\text { (preservation of historical memory) Heritage }\end{array}$ \\
\hline \multirow{3}{*}{ Economic strategy } & 6) Cost reduction \\
\hline & $\begin{array}{l}\text { 7) Increase of cohesion (accessibility and transportation) and economic dynamics } \\
\text { (employment and business) }\end{array}$ \\
\hline & 8) Multi-functionality of the territory, territorial competitiveness \\
\hline
\end{tabular}

This analysis includes the following: 1) A comprehensive inventory of sustainability areas covered by the literature, conducted in order to select the thematic fields that are encompassed in the sustainability dimensions used in neighborhood projects and/or in the redevelopment of brownfield projects. This inventory of thematic fields mainly includes the evaluation tools most commonly used by project actors, in research and in the existing fieldwork: LEED-ND [14], BREEAM Communities [15], CASBEE-UD, SBTool [43], and Green Star [18]; it also takes into account 2) a selection and aggregation of the thematic areas most often addressed in these studies; and 3) a selection of criteri, a including sustainability aspects. The choice guided by these criteria thus makes it possible to classify the thematic fields into three dimensions: Environmental, socio-cultural, and economic. Revisiting neighborhood-level assessment systems (such as LEED-ND, BREEAM Communities, CASBEE-UD, SBTool, and Green Star), the 21 articles analyzed and case studies conducted on this topic, revealed 
that The concept and approaches used in brownfield remediation are evolving to encompass all areas of sustainability and not to introduce more ambiguous and complex indicators, but to introduce levers, linkages and contextualization [5]. In addition, although the evaluation tools (LEED, CASBEE, BREEAM, SBTool, and Green star) are well structured, but its indicators are generic and do not evaluate the brownfield in the context where it is located.

In academic work, the main differences between the assessment tools and the methodological approaches analyzed in the literature review tend to be more proactive and positive. They have no specific requirements on how to design or evaluate socio-economic aspects as well as environmental aspects with these indicators [53]. These approaches and models that we analyzed open a dialogue about the decision-making process but in some cases neglect to focus their attention on the site $[5,54,55]$. The application of these approaches depends largely on the context in which they are used and the designers who use them [28]. Therefore, the use of these frameworks is limited to the initial phases of the project and they are never used in an ex-post evaluation of the project [53]. These approaches, as stated [23], can complement existing evaluation systems by enabling dialogue, reflection and learning, by integrating the specificity of places and contexts, in particular the benefits that a redevelopment of wastelands have on the ground. environment and the city $[5,9,17]$. The choice guided by these criteria makes it possible to classify the thematic areas in three dimensions: Environmental, socio-cultural, and economic. These three dimensions are then translated into eight thematic fields, summarized in Table 3.

The research considers a selection related to the restructuring of case studies of North American and European brownfields. Table 4 provides a detailed description of the indicators used in each case study and the objectives identified for each project. By analysing Table 4, it can be observed that the number of indicators considered is different for each author in each thematic field.

To identify and classify the most relevant indicators in brownfield redevelopment projects, the Geographical Information System (GIS) and multi-criteria analysis for the prioritization of indicators in each thematic field were used. The GIS was used to identify indicators associated with their territory that are useful for assessing the context of a site and its surroundings.

As shown in Figure 2, the use of G.I.S. has consisted in selecting services all inside the brownfield and also in its surroundings. In this phase the use of G.I.S. was used to select the functions of the services related to the territory. In this way we will identify the indicators that are in relation with the neighboring territory to better contextualize the project to the territory.

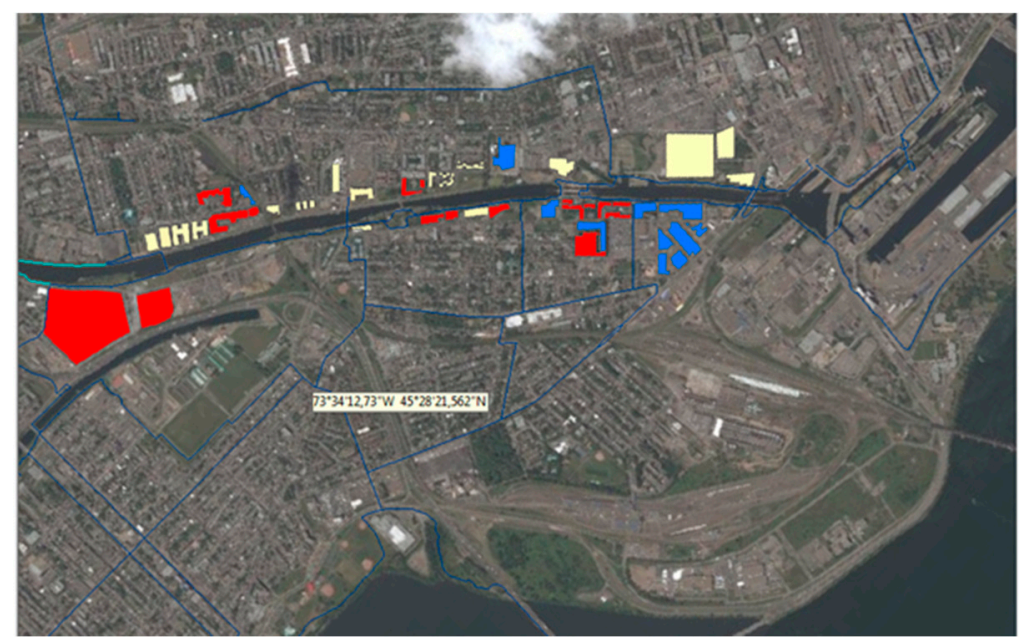

Figure 2. Use of G.I.S. in the Brownfield Lachine Canal (Montréal, Canada). Legend: In red the industrial buildings; in yellow the new constructions and in blue the historical building and the blue lines the bicycle paths. 
Table 4. Indicators found in the literature.

\begin{tabular}{|c|c|c|c|c|c|c|c|c|}
\hline \multirow{3}{*}{ Author } & \multicolumn{8}{|c|}{ Number Indicators } \\
\hline & \multicolumn{3}{|c|}{ Environmental } & \multicolumn{2}{|c|}{ Social and Cultural } & \multicolumn{3}{|c|}{ Economy } \\
\hline & $\begin{array}{l}\text { Thematic } \\
\text { Field } 1\end{array}$ & $\begin{array}{l}\text { Thematic } \\
\text { Field } 2\end{array}$ & $\begin{array}{l}\text { Thematic } \\
\text { Field } 3\end{array}$ & $\begin{array}{c}\text { Thematic } \\
\text { Field } 4\end{array}$ & $\begin{array}{l}\text { Thematic } \\
\text { Field } 5\end{array}$ & $\begin{array}{l}\text { Thematic } \\
\text { Field } 6\end{array}$ & $\begin{array}{l}\text { Thematic } \\
\text { Field } 7\end{array}$ & $\begin{array}{c}\text { Thematic } \\
\text { Field } 8\end{array}$ \\
\hline [46] & & 1 & & \multicolumn{2}{|c|}{8} & \multicolumn{3}{|c|}{5} \\
\hline [7] & 4 & 4 & 5 & 3 & 5 & 3 & 3 & 3 \\
\hline [19] & 6 & 4 & 7 & 12 & 9 & 5 & 4 & 4 \\
\hline$[30]$ & 2 & 2 & 6 & 9 & 11 & 3 & 4 & 3 \\
\hline [2] & & 1 & & \multicolumn{2}{|c|}{1} & \multicolumn{3}{|c|}{9} \\
\hline$[44]$ & & 9 & & 12 & 4 & & 8 & \\
\hline [36] & & 2 & & \multicolumn{2}{|c|}{6} & \multicolumn{3}{|c|}{3} \\
\hline [47] & & 5 & & \multicolumn{2}{|c|}{5} & \multicolumn{3}{|c|}{5} \\
\hline [42] & 8 & 3 & 3 & 11 & 7 & 4 & 2 & 2 \\
\hline [37] & & 4 & & \multicolumn{2}{|c|}{4} & \multicolumn{3}{|c|}{2} \\
\hline [48] & 0 & 0 & 0 & 0 & 0 & & 2 & \\
\hline [49] & & 9 & & \multicolumn{2}{|c|}{5} & \multicolumn{3}{|c|}{8} \\
\hline [33] & & 7 & & \multicolumn{2}{|c|}{6} & \multicolumn{3}{|c|}{1} \\
\hline [39] & & 5 & & \multicolumn{2}{|c|}{4} & \multicolumn{3}{|c|}{3} \\
\hline [4] & 4 & 2 & 2 & 5 & 6 & 3 & 2 & 2 \\
\hline [34] & & 4 & & \multicolumn{2}{|c|}{4} & \multicolumn{3}{|c|}{9} \\
\hline [5] & 7 & 6 & 5 & 9 & 9 & 4 & 11 & 9 \\
\hline
\end{tabular}

As shown in Table 4, we used the thematic fields of Table 3 and associated the indicators identified in the analysis of the studies considered with one or more of the eight fields. The first column refers to the source of reference (Author) where each indicator was found. The analysis highlighted that authors who use a high number of indicators are those who diversify them into multiple thematic fields.

The other indicators from the literature and evaluation tools were categorized and prioritized using the Analytic Hierarchy Process (AHP). In this way we could weigh the indicators by assigning a weight to each according to its importance (for example, the number of times it is used in the literature). The final list of indicators will be used in the methodological approach we propose in Section 5. We assigned a weight of 1 to each indicator that was quoted at least 16 times and more, 0.75 if quoted at least $11,0.5$ if cited six times or more, and 0.25 if indicator have been cited less than six times. In Table 5 the weight assigned based to indicator frequency. After assigning a weight to each indicator before integrating them into our methodological approach, we perform a peer comparison for prioritization using hierarchical multi-criteria analysis (AHP), categorizing them in order of their importance (see Table 6).

Table 5. Weight assigned based to frequency indicator.

\begin{tabular}{ccccc}
\hline \multicolumn{2}{c}{ Range } & & & \\
\hline $\begin{array}{c}\text { Number citations indicators } \\
\text { In the literature and assessment tools }\end{array}$ & $\leq 5$ & $6 \leq 10$ & $11 \leq 15$ & $\geq 16$ \\
\hline Weight assigned & 0.25 & 0.50 & 0.75 & 1 \\
\hline
\end{tabular}


Table 6. Selected redevelopment indicators and their assigned weights.

\begin{tabular}{|c|c|c|c|}
\hline Indicators & Weight & Indicators & Weight \\
\hline Infrastructure system water; & 1 & Accessibility; & 1 \\
\hline Water consumption (including water & 1 & Public spaces; & 1 \\
\hline quality) $\left(\mathrm{m}^{3}\right)$ & 1 & Inclusion; & 1 \\
\hline Energy consumption $(\mathrm{Kw})$; & 1 & Security; & 1 \\
\hline Green spaces $\left(\mathrm{Km}^{2}\right)$ & 1 & Urban frame (density); & 1 \\
\hline Water surface (Quality); & 0.5 & Public areas (Parks, living & 1 \\
\hline Vegetation (Type) & 1 & areas); & 0.75 \\
\hline Use of space; Living areas; & 1 & Diversity (religion, income, & 1 \\
\hline Landscape (unnatural barrier, bridges, & 0.5 & race); & 0.25 \\
\hline viaducts); & 0.5 & Population density & 0.75 \\
\hline Enhancing biodiversity; & 0.5 & (person/ha); & 1 \\
\hline Morphology; & 0.5 & Marginal Green (ha/street km); & 1 \\
\hline River system (Km) & 0.5 & House Diversity (Number of & 1 \\
\hline Ventilation; & 0.5 & each Type of House); & 0.5 \\
\hline Physical comfort; & 1 & Land Use Diversity; & 0.75 \\
\hline Proportion of own sites; & 1 & Politics inquiries (Number); & 0.75 \\
\hline Soil quality (\% of contaminants); & 1 & Crimes (Number) & 1 \\
\hline Lighting (orientation); & & Structure; & 0.5 \\
\hline Heat islands $(\mathrm{UHI})\left({ }^{\circ} \mathrm{C}\right)$ & & Materials; & 0.5 \\
\hline Waste management; & 1 & Technology; & 0.5 \\
\hline Distribution functions (Number for & 1 & $\begin{array}{l}\text { Care and maintenance; } \\
\text { Form. }\end{array}$ & \\
\hline Area); & 1 & $\begin{array}{l}\text { Form; } \\
\text { Architectural fraomentation. }\end{array}$ & \\
\hline Service - Business (Number); & 0.5 & Architectural fragmentation; & \\
\hline Contiguity; & 1 & & \\
\hline Distance to primary school $(\mathrm{km})$; & 1 & & \\
\hline Distance to high school (km); & 0.25 & & \\
\hline Distance to mosque $(\mathrm{km})$ & 0.25 & & \\
\hline Distance to catholic church $(\mathrm{km})$ & 0.25 & & \\
\hline Distance to Anglican church (km); & 1 & & \\
\hline Distance to health center $(\mathrm{km})$ & 0.75 & & \\
\hline Distance to airport $(\mathrm{km})$ & 1 & & \\
\hline Streets network; & 1 & & \\
\hline Public transport (Frequency); & 1 & & \\
\hline Fluidity of movement (Number O/D); & 1 & & \\
\hline Parking (Number and Type); & 1 & & \\
\hline Links, connections; & 1 & & \\
\hline Economic diversification; & 0.75 & & \\
\hline Number of jobs (Number); & 0.75 & & \\
\hline Job Type (Number); & 0.5 & & \\
\hline Total income $(\$)$ & 1 & & \\
\hline Connections (Type and Number); & 1 & & \\
\hline Partition areas $\left(\mathrm{m}^{2}\right)$ & 0.25 & & \\
\hline Urban form ( urban fabric ); & 0.75 & & \\
\hline Public areas $\left(\mathrm{Km}^{2}\right)$ & 1 & & \\
\hline Historical activities (N. h.a./Job type) & & & \\
\hline
\end{tabular}

\subsection{Classification Andintegration of Indicators in a Methodological Framework (Third Step)}

In this step, we integrate the indicators selected in the previous step in each dimension and thematic area and then build the methodological approach that we will explain in Section 5. Table 7 summarizes the selected and classified indicators in each dimension.

The list of actions presented here integrated in Table 10 are those that according to the analysis made have priority and must be taken into consideration (Natural Resource Management, Biodiversity, Quality of natural areas, Environmental protection, Improved comfort and health, Strengthening cohesion and social equity, Enhancement of the architectural and historical heritage, Cost reduction, Increase of cohesion and economic dynamics, Multi-functionality of the territory, Territorial competitiveness). 
These redevelopment indicators taken into account are balanced in the three dimensions (environmental, social, and economic) because they evaluate the particularity of the site, but also the context where this site is and this is important if we want to build sustainable neighborhoods.

Table 7. Redevelopment indicators integrated in each dimension.

\begin{tabular}{|c|c|}
\hline Dimension & Indicators \\
\hline Environmental & $\begin{array}{l}\text { Infrastructure system water; Water consumption (including water quality) }\left(\mathrm{m}^{3}\right) \text {;Energy } \\
\text { consumption }(\mathrm{Kw}) \text {; Green spaces }\left(\mathrm{Km}^{2}\right) \text {; Water surface (Quality); Vegetation (Type) } \\
\text { Use of space; Living areas; Landscape (unnatural barrier, bridges, viaducts); Enhancing } \\
\text { biodiversity; Morphology; River system (Km) } \\
\text { Ventilation; Physical comfort; Proportion of own sites owned; Soil quality; Lighting } \\
\text { (orientation); Heat islands (UHI) }\left({ }^{\circ} \mathrm{C}\right)\end{array}$ \\
\hline Social and cultural & $\begin{array}{c}\text { Accessibility; Public spaces; Inclusion; Security; Urban framework (density); Public } \\
\text { areas (Parks, living areas); Diversity (religion, income, race); Population density } \\
\text { (person/ha); Marginal Green (ha/street km); House Diversity (Number of each Type of } \\
\text { House); Land Use Diversity; Politics inquiries (Number); Crimes (Number) } \\
\text { Structure; Materials; Technology; Care and maintenance; Form; Architectural } \\
\text { fragmentation; Architectural quality }\end{array}$ \\
\hline Economic & $\begin{array}{l}\text { Waste management; Distribution functions; Service - Business; Contiguity; Distance to } \\
\text { primary school (km); Distance to high school (km); Distance to mosque (km); Distance } \\
\text { to catholic church (km); Distance to Anglican church }(\mathrm{km}) \text {; Distance to health center } \\
\qquad(\mathrm{km}) \text {; Distance to airport }(\mathrm{km}) \\
\text { Streets network; Public transport; Fluidity of movement; Parking; Links, connections; } \\
\text { Economic diversification; Number of jobs; Job types (Number); Total income } \\
\text { (\$/household); } \\
\text { Connections; Partition areas; Urban form (urban fabric); Public areas; Historical } \\
\text { activities (N. h.a./Job type) }\end{array}$ \\
\hline
\end{tabular}

\section{Construction of the Methodological Approach (Analysis Results)}

The redevelopment project of a territory structures its organization according to the stages of a construction project in general. The difference is that a brownfield redevelopment project has to take into account its past (land use), all the existing buildings (reuse and cultural interest) and the contextualization scale (urban or rural extra urban), along with the associated environmental issues. In our proposal, the urban redevelopment project is based on the same stages of the life cycle of a construction project. This perspective allowed us to include some fundamental steps in the life cycle of a project. Our proposal emphasizes that certain steps must be well-identified in order to achieve the expected goals at the end of the project. Figure 3 indicates the basic steps of a redevelopment project. It is clear that this scheme can be applied to any kind of urban project.

\section{Life cycle project}

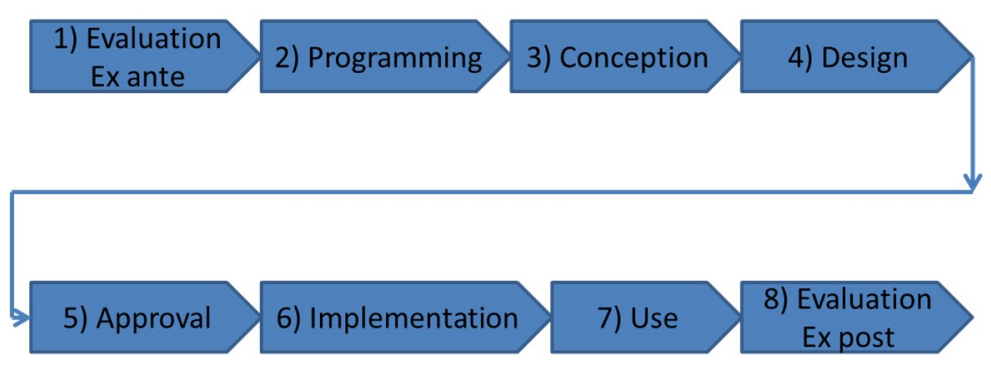

Figure 3. The phases of an urban redevelopment project (Régie du bâtiment Québec, 2013—the processis designed by authors). 
We propose that the stakeholder groups we have identified must be involved in urban redevelopment projects. We classified the actors into eight groups (Table 8). These stakeholder groups are each involved in a different way at each stage of a project. With the identification of the actors involved at each phase, their roles and the governance logic of the project can be detailed.

Table 8. Involvement of stakeholder groups in a project's phases.

\begin{tabular}{|c|c|c|c|c|c|c|c|c|}
\hline $\begin{array}{l}\text { Stakeholders } \\
\text { Groups }\end{array}$ & Ex ante & Programming & Conception & Design & Approval & Implementation & Use & Expost \\
\hline $\begin{array}{c}\text { National } \\
\text { policy makers }\end{array}$ & & $x$ & & & $x$ & & & \\
\hline $\begin{array}{l}\text { Local policy } \\
\text { makers }\end{array}$ & $x$ & $x$ & $x$ & & $x$ & $x$ & & $x$ \\
\hline $\begin{array}{l}\text { Institutions } \\
\text { and } \\
\text { associations }\end{array}$ & & $x$ & & $x$ & $x$ & $x$ & $x$ & $x$ \\
\hline $\begin{array}{l}\text { Project } \\
\text { Sponsors }\end{array}$ & & $x$ & & $x$ & & & & \\
\hline Experts & & $x$ & & $x$ & & & & $x$ \\
\hline Consultants & $x$ & & & $x$ & & & & $x$ \\
\hline $\begin{array}{l}\text { Operational } \\
\text { actors }\end{array}$ & & & $x$ & & & $x$ & & \\
\hline Users & $x$ & & & $x$ & $x$ & $x$ & $x$ & \\
\hline
\end{tabular}

\subsection{Identification Indicators and Stakeholders' Positioning}

Our methodological approach is inspired by the analysis of the decision support tools found in selected articles that take into account economic, social and environmental aspects. All of the approaches incorporate the fundamental issues of a project, including the definition of the objectives and indicators related to its urban scale (Table 9).

Table 9. Positioning of stakeholder groups in the dimensions and life cycle a project.

\begin{tabular}{|c|c|c|c|c|c|c|c|c|}
\hline \multirow{3}{*}{$\begin{array}{l}\text { Life Cycle } \\
\text { Project }\end{array}$} & \multicolumn{8}{|c|}{ Dimensions } \\
\hline & \multicolumn{3}{|c|}{ Environmental } & \multicolumn{2}{|c|}{ Social } & \multicolumn{3}{|c|}{ Economic } \\
\hline & $\begin{array}{l}\text { Thematic } \\
\text { Env. } 1\end{array}$ & $\begin{array}{l}\text { Thematic } \\
\text { Env. } 2\end{array}$ & $\begin{array}{l}\text { Thematic } \\
\text { Env. } 3\end{array}$ & $\begin{array}{l}\text { Thematic } \\
\text { Soc. } 4\end{array}$ & $\begin{array}{l}\text { Thematic } \\
\text { Soc. } 5\end{array}$ & $\begin{array}{l}\text { Thematic } \\
\text { Eco. } 6\end{array}$ & $\begin{array}{l}\text { Thematic } \\
\text { Eco. } 7\end{array}$ & $\begin{array}{l}\text { Thematic } \\
\text { Eco. } 8\end{array}$ \\
\hline Programming & (1)(2)(5) & (1)(2)(5) & (1)(5) & (2)(5) 7 & (2) & (2) & (2) & (2) \\
\hline Conception & (2)(3)(5)(6) & (2)(3)(5)(6)(7) 8) & (2) & (3)(2)(4)(5)(6)(8) & (2) 8 & (4) & (4) & (2) \\
\hline Approval & (2)(3)(5)(6)(7) & (2)(3)(5)(6)(7) & (2)(3)(4)(5)(6)(7) & (2)(3)(4)(5)(6) & (2)(3)(5)(6) & (4)(7) & & (2) \\
\hline Implementation & (2)(3)(4)(5)(6)(7) & (2)(3)(4)(5)(6)(7) & (2)(3)(4)(5)(6)(7) & (2)(3)(4)(5)(6) & (2)(3)(5)(6) & (4)(7) & & (2) \\
\hline Use & (2)(8)(5)6) & (5)(6) & (5)(6) & 8 & 8 & & & \\
\hline $\begin{array}{l}\text { Ex Post } \\
\text { Evaluation }\end{array}$ & (2)(5)(6) & (5)(6) & (5)(6) & (2)(5)(6) & (2)(5)(6) & (5)(6) & (2)(5)(6) & (2)(5)(6) \\
\hline
\end{tabular}

Legend: (1) National policy makers; (2) Local policy makers; (3) Institutions/Associations; (4) Project Sponsors; (5) Experts; (6) Consultants; (7) Operational actors; and (8) Users.

Most of the tools and approaches we found are focused on the environmental and social aspects of urban spaces, while our study is more oriented towards the integration of sustainability in a brownfield redevelopment project (socio-economic aspects) in an urban context (neighbourhood).

However, this method does allow us to build an approach in the formulation of a project's issues and criteria. As a first step, the methodological approach is based on the thematic fields identified for each dimension, and then on the actions to be taken. This is interpreted on three levels: the thematic fields are first translated into actions to be carried out in general and then into objectives, and finally 
into parameters to be addressed. The implementation of these actions and themes comes from an analysis of the existing tools, data, and information collected.

To better organize all the data collected to date, we assembled selected stakeholder groups with their dimensions in order to understand how these groups of actors intervene during the life cycle of an urban redevelopment project. Analyzing Table 9 allows us to understand how the actors are involved during the decision-making process and in the definition of a project's objectives.

\subsection{Integration of Indicators into Dimensions}

The indicator integration process is based on the following considerations:

Inventory of the (territorial) dimensions and actions, parameters or indicators most often mentioned;

Eliminate any redundancies of repeated items; and Compare themes with studies to identify those with the similar direction (scale, context, etc.).

The dimensions were then presented within hierarchical structures (according to the traditional dimensions of sustainable development), in the form of the actions to be undertaken for each thematic field and the themes to be addressed (the targets of these actions). Then, we identify the parameters to be evaluated. After identifying the three factors (processes, actors, thematic fields) structuring the projects of sustainable neighborhood, we put them into perspective by developing an analysis grid. The grid is an interface for integrating thematic fields of sustainable development into the project process. The objective is to position and relate the problems and the essential factors identified in a global and complex vision to characterize a project of urban revitalization. The purpose of this approach is to establish the level of complexity of the problem as well as to form a structure of the criteria with which to establish the actions to be taken to achieve the redevelopment. To integrate the aspects of sustainable urban development, the dimensions are cross-linked with the project's parameters to translate the objectives for a project's development. The thematic fields are then selected from this crossing to identify the most-important issues to consider for successful integration (see Table 7).

It is assumed that between the themes and phases of project design there are links to arrive at intelligent redevelopment objectives. For example, architectural heritage enhancement is related to urban form and to the historic preservation of buildings. There is also a link to the multi-functionality of services, the use of the territory and the social relations of citizens and economic activity at the industrial site. The proposed approach aims to contribute to brownfield redevelopment by transforming the traditional project criteria to support a sustainable redevelopment approach in which stakeholders use these criteria as the basis of communication with other stakeholders.

The list of criteria is based on two groups of data. All of the themes proposed for sustainable redevelopment earlier in our analysis were expressed as a set of criteria for the design of a sustainable brownfield redevelopment. In practice, by crossing each theme with each parameter we were able to establish the integration criteria. This was done with the intention to collect and consolidate criteria that meet different objectives with the parameters of design, as well as to assemble the same practical criteria. Table 10 shows the linking of actions with the parameters of the redevelopment setting (indicators). 
Table 10. Redevelopment settings.

\begin{tabular}{|c|c|}
\hline Actions & Indicators \\
\hline $\begin{array}{l}\text { Natural Resource Management (Storm } \\
\text { water, sewage, alternative energy, etc.), } \\
\text { biodiversity, quality of natural areas }\end{array}$ & $\begin{array}{l}\text { Infrastructure system water; Water consumption (including } \\
\text { water quality) }\left(\mathrm{m}^{3}\right) \text {;Energy consumption (Kw); Green spaces } \\
\left(\mathrm{Km}^{2}\right) \text {; Water surface (Quality); Vegetation (Type) }\end{array}$ \\
\hline $\begin{array}{l}\text { Environmental protection (floodplains, } \\
\text { rivers, lakes, wetlands, parks, animals, etc.) }\end{array}$ & $\begin{array}{c}\text { Use of space; Living areas; Landscape (unnatural barrier, } \\
\text { bridges, viaducts); Enhancing biodiversity; Morphology; River } \\
\text { system (Km) }\end{array}$ \\
\hline $\begin{array}{l}\text { Improved comfort and health (pollution of } \\
\text { the site ) }\end{array}$ & $\begin{array}{l}\text { Ventilation; Physical comfort; Proportion of own sites owned; } \\
\text { Soil quality; Lighting (orientation); Heat islands (UHI) }\left({ }^{\circ} \mathrm{C}\right)\end{array}$ \\
\hline $\begin{array}{l}\text { Enhancement of the architectural (buildings } \\
\text { and materials) and historical (preservation } \\
\text { of historical memory) heritage }\end{array}$ & $\begin{array}{c}\text { Accessibility; Public spaces; Inclusion; Security; Urban } \\
\text { framework (density); Public areas (Parks, living areas); } \\
\text { Diversity (religion, income, race); Population density } \\
\text { (person/ha); Marginal Green (ha/street km); House Diversity } \\
\text { (Number of each Type of House); Land Use Diversity; Politics } \\
\text { inquiries (Number); Crimes (Number) } \\
\text { Structure; Materials; Technology; Care and maintenance; Form; } \\
\text { Architectural fragmentation; Architectural quality }\end{array}$ \\
\hline Cost reduction & Waste management; Distribution functions; Service - Business; \\
\hline $\begin{array}{l}\text { Increase of cohesion (accessibility and } \\
\text { transportation) and economic dynamics } \\
\text { (employment and business) }\end{array}$ & $\begin{array}{l}\text { Contiguity; Distance to primary school }(\mathrm{km}) \text {; Distance to high } \\
\text { school }(\mathrm{km}) \text {; Distance to mosque }(\mathrm{km}) \text {; Distance to catholic } \\
\text { church }(\mathrm{km}) \text {; Distance to Anglican church }(\mathrm{km}) \text {; Distance to } \\
\text { health center }(\mathrm{km}) \text {; Distance to airport }(\mathrm{km}) \\
\text { Streets network; Public transport; Fluidity of movement; }\end{array}$ \\
\hline $\begin{array}{l}\text { Multi-functionality of the territory, } \\
\text { territorial competitiveness }\end{array}$ & $\begin{array}{l}\text { Parking; Links, connections; Economic diversification; Number } \\
\text { of jobs; Job types (Number); Total income (\$/household); } \\
\text { Connections; Partition areas; Urban form (urban fabric); Public } \\
\text { areas; Historical activities (N. h.a./Job type) }\end{array}$ \\
\hline
\end{tabular}

\section{Discussions}

Thus far, the study has only revealed partial results, as there is not much specific literature that considers the tangible socio-economic aspects in brownfield development. Most studies that consider environmental issues prioritize soil contamination and decontamination. New criteria are essential for sustainable development solutions, and for brownfield rehabilitation. The tools used by professionals and municipalities have their shortcomings in terms of project evaluation. A tool must be able to clearly identify a project's objectives, and to classify and prioritize them based on local interests. The need for regeneration of the natural environment, including the landscape and biodiversity should be a priority $[42,54]$.

As Pan det al. (2019) affirms, traditional methods of urban rehabilitation and land use neglect socio-economic causes. It is clear to us that without the inclusion of feedback to remove uncertainties, such an approach could significantly underestimate the resulting impacts on ecosystem services $[9,17]$. Therefore, considering this aspect, it is necessary to build a dynamic and retroactive method that integrates human activities and environmental processes into decision-making [9] in order to assess their impacts. Socio-economic and environmental processes to build local indicators that better assess the territory [5].

The quality of brownfield conversion is related to meeting users' expectations for the rehabilitation of these sites. This can be attained through the use of suitable indicators. As stated by Willians and Dair (2007) and Ballesteros and Ramirez (2007), cited in Sardinha et al. (2013) [39], attachment to cultural heritage must be among the objectives of redevelopment projects because of the influence of the concepts of landscape and the social aspects of the community. The indicators related to the conditions of public safety, accessibility, etc., also need to be part of the redevelopment of brownfields $[42,47,54,56]$. 
A new methodological framework characterized by a multi-criteria, transversal, and comprehensive approach is a requirement for moving towards sustainable redevelopment.

\subsection{Alignment with Other Theories and Works}

Our methodological approach is in line with other studies that have touched on the problem of sustainable neighborhood development and the evaluation of sustainability. One example is Sharifi and Murayama (2014) [43], who identified some of the shortcomings in the most commonly-used evaluation tools in their neighborhood sustainability studies. Their work highlighted the need for a methodological approach to co-evolve and optimize decision-making, as well as to optimize existing tools.

Another study, conducted by Haapio (2011) [14] and focused on decision-making and the importance of a methodological approach, found that evaluation tools and systems (BREEAM Communities and LEED) are increasingly used by investors, promoters and real estate developers to support their projects from an economical perspective. Haapio observed that the tools need improvement, especially in terms of their indicators, and that they should be used for decision-making. His study concludes by with a call for a methodological approach, where the participation of authorities, planners and designers will help improve the process of decision-making, especially in an urban context.

Mori and Christodoulou (2012) [32] focused on the development of a methodological approach for the evaluation of cities and the use of local indicators. They showed how in a valid sustainability evaluation, it is imperative to take into account environmental factors and economic and social aspects (the triple objectives of sustainability). They also affirm the need to create indices/indicators capable of evaluating the world's cities in developed and developing countries by using common lines of assessment.

An earlier work conducted by Moussiopoulos et al. (2010) [41] focused on the use of indicators to assess the sustainability of cities in a case study on the metropolitan area of Thessaloniki in Greece, they argue that measuring sustainability in urban areas is a major challenge for managers and decision-makers. They aimed to develop and use a system of indicators for the management of environmental, social, and economic information to assess sustainability in urban areas, thereby improving the communication between stakeholders in the development process of development.

In summary, it is clear that the roles played by community groups and other decision-makers indicate that there are a variety of strategies for implementing the sustainability assessment. Indeed, we have been able to show that a community approach allowing actors to carry out a joint evaluation of a project is desirable. We have shown that the roles of stakeholder groups evolve over time and in different phases of the project life cycle. It is the communication between them that can set up an effective methodological evaluation method. In the end, we can say that the different roles can actually be rather complementary, and that the active participation of all of the stakeholder groups will undoubtedly promote sustainability in urban contexts.

\section{Conclusions and Future Work}

The sustainable development approach has led to a renewal of the conceptual issues of project development. The new criteria resulting from the crossing of thematic issues with the parameters of project design allow for better control of a project's implementation. These improvements are especially notable in the early stages of programming and project design. However, it is interesting to note that the success of such an approach in the context of a development project depends on the contributions of all of a project's stakeholders, and not only on national and local policy makers. What we can say is that each stakeholder group involved in the decision-making process must contribute by interacting with other decision-makers. Local and federal public actors must seek to compensate for investors' economic interests and local expectations. It is clear that economic interests should also be favored if we want the external supply of capital, but investors must also propose and leave room for social objectives by seeking to bring the resilience of their projects in an urban sustainable context. Roundtables and interviews in all phases of the project cycle will be useful for pursuing sustainable 
development goals and improving debate among all stakeholders. This is clearly demonstrated in the results of our crossing the thematic issues with project parameters: project development criteria fail to address several of the issues that are required for a successful urban redevelopment. Another consideration is the use of evaluation tools and the models used by stakeholders, as they have gaps in their structure. All the models concur that all three sustainability dimensions should be covered and that the social and environmental aspects should have greater amplitude, especially when planning brownfield developments. The tools assessed here are not able to adequately assess all three dimensions. Some indicators are related to urban forms but are not treated with the appropriate tools. Another observation is that the number of indicators becomes fewer representatives in some studies, and that project objectives sometimes take the place of indicators.

This study allows us to see the shortcomings of the tools used by professionals and municipalities, deduced from the intersection of the themes and indicators of the tools used in the case studies. The results of the analysis demonstrated that the methodological approach is structured to be used in different contexts. However, even if it is rigorously built, it is not without limits. One of the limits is that its structure can appear complex in the step of identifying the thematic fields and thus in the integration of the indicators. But, if we are able to differentiate the indicators in the early steps, the work should be less overwhelming. We plan to validate the methodological approach in case studies, and to use it in the early stages of a project's life cycle to allow for improvements if they are identified. We prefer to leave the methodology open to supplementary and continuous evolutions, as this methodology will require checks and balances to validate the developed tools.

\section{Patents}

This section is not mandatory, but may be added if there are patents resulting from the work reported in this manuscript.

Author Contributions: F.C. conceived the project, the main conceptual ideas and the outlines of proof and made numerical calculations for the suggested experiment. D.F. and M.G. developed almost all the technical details and verified the numerical results of the case study. F.C. wrote the manuscript.

Funding: This research received no external funding.

Acknowledgments: The authors would like to express their appreciation for two laboratories of the École de Technologie Supérieure-GRIDD and STEPPE_-for their financial support in conducting this study. Thanks should also go to all of the experts we consulted for their time and input during the realization of this article. Finally, much gratitude is extended to two anonymous reviewers for their valuable comments on this paper.

Conflicts of Interest: The authors declare no conflict of interest.

\section{References}

1. Bureau, U.C. World Population. 2015 [Cited 201726 November 2017]; Increase World and US Populations. Available online: https://www.census.gov/popclock/ (accessed on 23 April 2018).

2. Chen, Y.; Hipel, K.W.; Kilgour, D.M.; Zhu, Y. A strategic classification support system for brownfield redevelopment. Environ. Model. Softw. 2009, 24, 647-654. [CrossRef]

3. United States Environmental Protection Agency. United States Environmental Protection Agency 2004. Brownfields Utilization, Investment and Local Development (BUILD) Act. Available online: https://www. epa.gov/brownfields (accessed on 31 May 2018).

4. Bartke, S.; Schwarze, R. No perfect tools: Trade-offs of sustainability principles and user requirements in designing support tools for land-use decisions between greenfields and brownfields. J. Environ. Manag. 2015, 153, 11-24. [CrossRef] [PubMed]

5. Cappai, F.; Forgues, D.; Glaus, M. Socio-Economic Indicators for the Ex-Post Evaluation of Brownfield Rehabilitation: A Case Study. Urban Sci. 2018, 2, 100. [CrossRef]

6. Thomas, M.R. A GIS-based decision support system for brownfield redevelopment. Landsc. Urban Plan. 2002, 58, 7-23. [CrossRef] 
7. Thomas, M.R. A Weighted, Multi-Attribute, Site Prioritization and Selection Process for Brownfield Redevelopment. Environ. Pract. 2002, 4, 95-106. [CrossRef]

8. Conte, E.; Monno, V. The regenerative approach to model an integrated urban-building evaluation method. Int. J. Sustain. Built Environ. 2016, 5, 12-22. [CrossRef]

9. Pan, H.; Zhang, L.; Cong, C.; Deal, B.; Wang, Y. A dynamic and spatially explicit modeling approach to identify the ecosystem service implications of complex urban systems interactions. Ecol. Indic. 2019, 102, 426-436. [CrossRef]

10. Sharifi, A. From Garden City to Eco-urbanism: The quest for sustainable neighborhood development. Sustain. Cities Soc. 2016, 20, 1-16. [CrossRef]

11. Burnett, J. City buildings-Eco-labels and shades of green! Landsc. Urban Plan. 2007, 83, 29-38. [CrossRef]

12. Wackernagel, M.; Rees, W. Our Ecological Footprint: Reducing Human Impact on the Earth; New Society Publishers: Gabriola Island, BC, Canada; Philadelphia, PA, USA, 9445th edition (July 1, 1998).

13. De Sousa, C.A. Urban brownfields redevelopment in Canada: The role of local government. Can. Geogr. 2006, 50, 392-407. [CrossRef]

14. Haapio, A. Towards sustainable urban communities. Environ. Impact Assess. Rev. 2012, 32, $165-169$. [CrossRef]

15. Holden, M. Sustainability indicator systems within urban governance: Usability analysis of sustainability indicator systems as boundary objects. Ecol. Indic. 2013, 32, 89-96. [CrossRef]

16. Préfontaine, É. Effets mesurés de la réhabilitation des friches industrielles: transformations de la qualité de vie et des valeurs foncières de trois sites dans le sud-ouest de montréal. Master's Thesis, Université du Québec, Institut national de la recherche scientifique, Québec City, QC, Canada, 2008; 96p.

17. Nyerges, T.; Ballal, H.; Steinitz, C.; Canfield, T.; Roderick, M.; Ritzman, J.; Thanatemaneerat, W. Geodesign dynamics for sustainable urban watershed development. Sustain. Cities Soc. 2016, 25, 13-24. [CrossRef]

18. G.o.C.-T.B.o.C. Federal Contaminated Sites Inventory 2018 [cited 20184 October 2018]; The Federal Contaminated Sites Inventory Includes Information on All Known Federal Contaminated Sites under the Custodianship of Departments, Agencies and Consolidated Crown Corporations. Available online: https://www.tbs-sct.gc.ca/fcsi-rscf/home-accueil-eng.aspx (accessed on 3 September 2018).

19. De Sousa, C.A. Turning brownfields into green space in the City of Toronto. Landsc. Urban Plan. 2003, 62, 181-198. [CrossRef]

20. Adams, D.; Watkins, C.; White, M. Planning, Public Policy and Property Markets; Wiley: Sheffield, Great Britain, 2005.

21. LEED-ND. Green Building Council in the US. 2015 [Cited 2015 16/11/2015]. Available online: http://www. usgbc.org/resources/leed-v4-neighborhood-development-current-version (accessed on 1 February 2018).

22. BREEAM, C. British organization BRE Global. 2015. Refurbishment and Fit-Out Technical Standard. 2015. Available online: https://www.breeam.com/discover/technical-standards/refurbishment-and-fit-out/ (accessed on 26 November 2018).

23. CASBEE-UD. IBEC 2014 [Cited 2015 09/11/2015]. Available online: http://www.ibec.or.jp/CASBEE/english/ toolsE_urban.htm (accessed on 26 November 2018).

24. (iiSBE), I.I.f.a.S.B.E. SBTool. 2018 [Cited 20182 August 2016]; iiSBE Is an International Non-Profit Organization Whose Overall Aim is to Actively Facilitate and Promote the Adoption of Policies, Methods and Tools to Accelerate the Movement towards a Global Sustainable Built Environment. iiSBE Has an International Board of Directors from Almost Every Continent and Has a Small Secretariat Located in Ottawa, Canada. Available online: http://www.iisbe.org/about (accessed on 2 August 2018).

25. Sharifi, A.; Murayama, A. A critical review of seven selected neighborhood sustainability assessment tools. Environ. Impact Assess. Rev. 2013, 38, 73-87. [CrossRef]

26. Kepaptsoglou, K.; Karlaftis, M.G.; Gkotsis, I.; Vlahogianni, E.; Stathopoulos, A. Urban Regeneration in Historic Downtown Areas: An Ex-Ante Evaluation of Traffic Impacts in Athens, Greece. Int. J. Sustain. Transp. 2015, 9, 478-489. [CrossRef]

27. Cappai, F.; Forgues, D.; Glaus, M. The Integration of Socio-Economic Indicators in the CASBEE-UD Evaluation System: A Case Study. Urban Sci. 2018, 2, 28. [CrossRef]

28. Cappai, F.; Forgues, D.; Glaus, M. Integrating An Environmental and Socio-Economic Assessment Tool for the Development of Brownfield Development Projects. Available online: ttp://vdf.ch/expanding-boundaries.html (accessed on 1 May 2019). 
29. Pan, H.; Deal, B. Reporting on the Performance and Usability of Planning Support Systems-Towards a Common Understanding. Appl. Spat. Anal. Policy 2019, 1-23. [CrossRef]

30. Wedding, G.C.; Crawford-Brown, D. Measuring site-level success in brownfield redevelopments: A focus on sustainability and green building. J. Environ. Manag. 2007, 85, 483-495. [CrossRef]

31. Bacot, H. Establishing Indicators to Evaluate Brownfield Redevelopment. Econ. Dev. Q. 2006, 20, $142-161$. [CrossRef]

32. Mori, K.; Christodoulou, A. Review of sustainability indices and indicators: Towards a new City Sustainability Index (CSI). Environ. Impact Assess. Rev. 2012, 32, 94-106. [CrossRef]

33. Cappuyns, V.; Kessen, B. Evaluation of the environmental impact of Brownfield remediation options: Comparison of two life cycle assessment-based evaluation tools. Environ. Technol. 2012, 33, 2447-2459. [CrossRef] [PubMed]

34. Beekmans, J.; Ploegmakers, H.; Martens, K.; van der Krabben, E. Countering decline of industrial sites: Do local economic development policies target the neediest places? Urban Stud. 2015. [CrossRef]

35. Chrysochoou, M.; Brown, K.; Dahal, G.; Granda-Carvajal, C.; Segerson, K.; Garrick, N.; Bagtzoglou, A. A GIS and indexing scheme to screen brownfields for area-wide redevelopment planning. Landsc. Urban Plan. 2012, 105, 187-198. [CrossRef]

36. Brill, C.W. using GIS to contrast perceived versus preferred priorities for Brownfield redevelopment in worcester, massachusetts. URISA J. 2009, 21, 49.

37. Rall, E.L.; Haase, D. Creative intervention in a dynamic city: A sustainability assessment of an interim use strategy for brownfields in Leipzig, Germany. Landsc. Urban Plan. 2011, 100, 189-201. [CrossRef]

38. Zimmermann, J.A.M.; Stevens, B.W. The use of performance measurement in South Carolina nonprofits. Nonprofit Manag. Leadersh. 2006, 16, 315-327. [CrossRef]

39. Sardinha, I.D.; Craveiro, D.; Milheiras, S. A sustainability framework for redevelopment of rural brownfields: Stakeholder participation at SÃO DOMINGOS mine, Portugal. J. Clean. Prod. 2013, 57, 200-208. [CrossRef]

40. Bramley, G.; Power, S. Urban form and social sustainability: The role of density and housing type. Plan. B: Plan. 2009, 36, 30-48. [CrossRef]

41. Moussiopoulos, N.; Achillas, C.; Vlachokostas, C.; Spyridi, D.; Nikolaou, K. Environmental, social and economic information management for the evaluation of sustainability in urban areas: A system of indicators for Thessaloniki, Greece. Cities 2010, 27, 377-384. [CrossRef]

42. Schadler, S.; Morio, M.; Bartke, S.; Rohr-Zanker, R.; Finkel, M. Designing sustainable and economically attractive brownfield revitalization options using an integrated assessment model. J. Environ. Manag. 2011, 92, 827-837. [CrossRef] [PubMed]

43. Sharifi, A.; Murayama, A. Neighborhood sustainability assessment in action: Cross-evaluation of three assessment systems and their cases from the US, the UK, and Japan. Build. Environ. 2014, 72, 243-258. [CrossRef]

44. Doick, K.; Sellers, G.; Castan-Broto, V.; Silverthorne, T. Understanding success in the context of brownfield greening projects: The requirement for outcome evaluation in urban greenspace success assessment. Urban For. Urban Green. 2009, 8, 163-178. [CrossRef]

45. Luederitz, C.; Lang, D.J.; Von Wehrden, H. A systematic review of guiding principles for sustainable urban neighborhood development. Landsc. Urban Plan. 2013, 118, 40-52. [CrossRef]

46. Greenberg, M.; Lewis, M.J. Brownfields Redevelopment, Preferences and Public Involvement: A Case Study of an Ethnically Mixed Neighbourhood. Urban Stud. 2000, 37, 2501-2514. [CrossRef]

47. Pediaditi, K.; Doick, K.J.; Moffat, A.J. Monitoring and evaluation practice for brownfield, regeneration to greenspace initiatives: A meta-evaluation of assessment and monitoring tools. Landsc. Urban Plan. 2010, 97, 22-36. [CrossRef]

48. Yu, S.; Unger, A.J.; Parker, B.; Kim, T. Allocating risk capital for a brownfields redevelopment project under hydrogeological and financial uncertainty. J. Environ. Manag. 2012, 100, 96-108. [CrossRef]

49. Chrysochoou, M.; Garrick, N.; Segerson, K.; Bagtzoglou, A.; Dahal, G.; Brown, K.; Granda-Carvajal, C. Reversing Urban Sprawl: A Reclaimability Index Approach for Reviving Downtown Brownfields; No. CTLS 08-03; Center for Transportation and Livable Systems (CTLS). Center for transportation and livable systems: New Haven, Connecticut, CT, USA, 2011. 
50. Cheng, F.; Geertman, S.; Kuffer, M.; Zhan, Q. An integrative methodology to improve brownfield redevelopment planning in Chinese cities: A case study of Futian, Shenzhen. Comput. Environ. Urban Syst. 2011, 35, 388-398. [CrossRef]

51. Ng, M.K.; Cook, A.; Chui, E.W.T. The Road Not Travelled: A Sustainable Urban Regeneration Strategy for Hong Kong. Plan. Pract Res.. 2001, 16, 171-183. [CrossRef]

52. A Rodenburg, C.; Wagtendonk, A.J.; Nijkamp, P. Success factors for sustainable urban brownfield development: A comparative case study approach to polluted sites. Ecol. Econ. 2002, 40, 235-252.

53. Samset, K.; Christensen, T. Ex Ante Project Evaluation and the Complexity of Early Decision-Making. Public Organ. Rev. 2017, 17, 1-17. [CrossRef]

54. Bäing, A.S.; Wong, C. Brownfield Residential Development: What Happens to the Most Deprived Neighbourhoods in England? Urban Stud. 2012, 49, 2989-3008. [CrossRef]

55. Shen, L.; Peng, Y.; Zhang, X.; Wu, Y. An alternative model for evaluating sustainable urbanization. Cities 2012, 29, 32-39. [CrossRef]

56. Thomas, M.R. The Use of Ecologically Based Screening Criteria in a Community-sponsored Open Space Preservation Programme. J. Environ. Plan. Manag. 2003, 46, 691-714. [CrossRef]

(C) 2019 by the authors. Licensee MDPI, Basel, Switzerland. This article is an open access article distributed under the terms and conditions of the Creative Commons Attribution (CC BY) license (http://creativecommons.org/licenses/by/4.0/). 